\title{
EMISSION FROM INLAND WATERWAY TRANSPORT IN THE CONTEXT OF ENERGY, CLIMATE AND TRANSPORT POLICY OF THE EUROPEAN UNION
}

DATA PRZESŁANIA: 21.04.2018, DATA AKCEPTACJI: 27.06.2018, JEL CODES: 054, P16, R49

\section{Emilia Kuciaba}

Wydział Zarządzania i Ekonomiki Usług, Uniwersytet Szczeciński emilia.kuciaba@wzieu.pl

The low emission mobility is one of the major goals of the European transport policy. Energy and climate policies accelerated the potential of transport to shift towards low emission mobility. In addition, promoting multimodality will strength the shift towards lower emission transport modes such as inland waterway transport and rail. Although inland waterway transport is not the main source of air pollution in the European Union, the modal shift may result in an increase of emissions from this mode of transport in the next years. The goal of this paper is to trace the issue of emissions from inland waterway transport in the context of European energy, climate and transport policy with particular attention to measures to reduce emissions in inland waterway transport.

In order to trace these issues, the latest energy, climate and transport policy documents were analyzed. There is also a comparison of the results of two research studies on emissions from inland vessels in order to describe its energy efficiency and the ability to interfere with the objectives set by the low emission policy.

Characteristics of the IWT are the longevity of the engines, less stringent emission limits for inland shipping compare to the other land-based modes of transport and the relatively small and specific market for inland vessels causes disadvantages of scale. These qualities determine most measures for reduction of emission in IWT.

The IWT vessels emit relatively few greenhouse gases, but can have rather high values for pollutant emissions, when compared to railways and trucks. Most measures for the reduction of emissions in IWT at the same time also reduce fuel consumption, and therefore have both ecological and economic benefits.

New strategy for low-emission mobility in inland waterway transport is electric power. Converting inland ships to electric power is an interface between technology and sustainability. Digitalization is necessary to improve the competitiveness of inland waterway transport. Digitalization is also the tool to provide multimodal integration. This could incentivize a modal shift towards inland waterway transport.

inland waterway transport, transport policy, energy and climate policy 


\section{INTRODUCTION}

The low emission mobility is one of the major goals of the European transport policy. Energy and climate policies accelerated the potential of transport to shift towards low emission mobility. In addition, promoting multimodality will strength the shift towards lower emission transport modes such as inland waterway transport and rail. Although inland waterway transport is not the main source of air pollution in the European Union, the modal shift may result in an increase of emissions from this mode of transport in the next years. The goal of this paper is to trace the issue of emissions frominland waterway transportin the context of European energy, climate and transport policy with particular attention to measures to reduce emissions in inland waterway transport.

Total volume of freight transport in EU-28 is 3,522 billion tonne-kilometres (tkm). The main modes of freight transport are road and maritime (with share of $49.0 \%$ and $31.9 \%$ of the modal split), followed by railway (11.7\%), inland navigation (4.3\%) and pipelines (3.2\%). Freight transport volumes are expected to grow even more than passenger transport. The EU Reference Scenario estimates an increase of $27,9 \%$ by 2030 and of $49,8 \%$ by 2050 (excluding maritime transport) (Siegemund, Trommler, Kolb, Zinnecker, 2017, p. 19).

The transport sector (including international aviation) accounts for $24,0 \%$ of all GHG emissions in the EU (table 1). GHG emission from transport sector raised from $15 \%$ in 1990 to $24 \%$ in 2016 (Eurostat, 2018). Road transport is the largest emitter, accounting for $72.8 \%$ of all GHG emissions from transport in 2016 (European Environment Agency, 2017).

Table 1. Sectoral GHG emissions in EU-28 (\%) (1990, 2016).

\begin{tabular}{|l|r|r|}
\hline \multirow{2}{*}{\multicolumn{1}{|c|}{ Sectors }} & \multicolumn{2}{c|}{ Share in GHG emissions } \\
\cline { 2 - 3 } & 1990 & 2016 \\
\hline Industrial processes and product use & 9.0 & 8.0 \\
\hline Transport (including international aviation) & 15.0 & 24.0 \\
\hline Waste Management & 4.0 & 3.0 \\
\hline Agricultural & 9.0 & 10.0 \\
\hline Fuel combustion and fugitive emissions from fuels (without transport) & 62.0 & 54.0 \\
\hline
\end{tabular}

Source: Eurostat (2018); European Environment Agency (2017).

The most relevant emissions from the transport modes are divided into two types (Market Observation Inland Navigation in Europe, 2017):

a) greenhouse gas emissions $(\mathrm{GHG})$ - including carbon dioxide $\left(\mathrm{CO}_{2}\right)$, methane $\left(\mathrm{CH}_{4}\right)$ and nitrous oxide $\left(\mathrm{N}_{2} \mathrm{O}\right)$;

b) pollutant emissions - including nitrogen oxides $\left(\mathrm{NO}_{\mathrm{x}}\right)$, particulate matter $(\mathrm{PM})$, hydrocarbons (HC) and carbon monoxide (CO).

Greenhouse gases (GHG) are treatedseparately since they do not have any direct toxic effects and are therefore,covered within the climate change cost category (Contribution..., 2013, p. 69). Pollutant emissions do not affect the climate directly, but they are harmful to air quality and human health. 
Although inland waterway transport has a small participation in the total amount of emissions from transport (about 0.5\% of total GHG from transport (European Environment Agency, 2017), locally this share can be very high. Cities like Cologne in Germany estimate that shipping contributes $25 \%$ of local NOx and $17 \%$ of PM emissions from transport. For Dusseldorf, the NOx contribution was estimated to be $41 \%$ of all transport NOx emissions (Clean Air campaign, 2018). In addition, $30 \%$ of ships cause more than $80 \%$ of the total emissions (Keuken et al., 2014). This may be the cause of the longevity of engines and less stringent emission limits for inland shipping compare to the other land-based modes of transport. Also, the relatively small and specific market for inland vessels causes disadvantages of scale.

\section{ENERGY, CLIMATE AND TRANSPORT POLICY OF THE EUROPEAN UNION}

One of the main challenges on the way of economic development is low-carbon economy (LCE). The concept of low-carbon economy (LCE) (Low-fossil-fuel economy (LFFE), decarbonized economy) based on low energy and material consumption and low emissions into the environment in all areas of the economy. Different sectors should participate in the transition to lowcarbon economy according to their technological and economic potential.

An essential component of the shift to the low-carbon, circular economy is low-emission mobility. It is needed for Europe to stay competitive and be able to cater to the mobility needs of people and goods (A European Strategy for Low-Emission Mobility COM/2016/0501 final).

At the Paris climate conference (COP21) in December 2015, 195 countries adopted the first universal, legally binding global climate deal. The agreement sets out a global action plan to put the world on track to avoid dangerous climate change by limiting global warming to well below $2^{\circ} \mathrm{C}$. The Paris Agreement is a bridge between today's policies and climate-neutrality before the end of the century (European Commission, climate negotiation, 2018).

In the EU context, the fight against climate change is generally split into two fields(Siegemund et al., 2017):

a) the sectors that fall under the EU Emissions Trading System (EU ETS); they are responsible for $45 \%$ of the emissions;

b) the sectors that are subject to the Effort Sharing Decision (ESD); they are responsible for $55 \%$ of the emissions.

Transport, along with other sectors such as buildings and agriculture, is the part of the ESD. As the transport sector is not included in the Emissions Trading Scheme (non-ETS sector), it is the responsibility of Member States to reduce transport emissions through national policies (for all non-ETS sectors, a 10\% reduction against 2005 levels by 2020 is foreseen), as opposed to sectors covered by the ETS (e.g. energy industries and industrial installations), where the emission reduction objective is to be achieved through an EU-wide trading scheme. From 1 January 2012, air transport has been included in the EU Emissions Trading System(European Environment Agency, 2017).

EU domestic legislation consist of:

- 2020 Climate and Energy Package,

- 2030 Climate and Energy Framework. 
The 2020 package is a set of binding legislation to ensure the EU meets its climate and energy targets for the year 2020. The package sets three key targets (2030 climate and energy framework, European Commission, 2018):

- $20 \%$ cut in greenhouse gas emissions (from 1990 levels),

- $20 \%$ of EU energy from renewables,

- $20 \%$ improvement in energy efficiency.

The targets were set by EU leaders in 2007 and enacted in legislation in 2009.

In October 2014 European Commission adapted the 2030 climate and energy framework, which tightens emission requirements in extended to 2030 time period. It sets three key targets for the year 2030 (2030 climate and energy framework, European Commission, 2018):

- at least $40 \%$ cuts in greenhouse gas emissions (from 1990 levels),

- at least $27 \%$ share for renewable energy,

- at least $27 \%$ improvement in energy efficiency.

The framework helps drive progress towards a low-carbon economy. It also brings environmental and health benefits - e.g. through reduced air pollution.The framework is in line with the longer term perspective set out in the Roadmap for moving to a competitive low carbon economy in 2050, the 2011 Energy Roadmap 2050 and the 2011 Transport White Paper.

In 2011 the EU set itself a long-term goal of reducing greenhouse gas emissions by $80-95 \%$, when compared to 1990 levels, by 2050 creating Energy Roadmap 2050. The European Commission's 2011 Energy Roadmap set out four main routes to a more sustainable, competitive and secure energy system in 2050: energy efficiency, renewable energy, nuclear energy, and carbon capture and storage (Energy Roadmap 2050 COM/2011/885).

European Union contributes to global policy by creating "Roadmap for moving to a competitive low carbon economy in 2050". The document suggests that (2050 low-carbon economy, European Commission, 2018):

a) by 2050 , the EU should cut greenhouse gas emissions to $80 \%$ below 1990 levels;

b) emissions from transport could be reduced to more than $60 \%$ below 1990 levels by 2050;

c) milestones to achieve this are $40 \%$ emissions cuts by 2030 and $60 \%$ by 2040 ;

d) the transition to a low-carbon society requires innovation and investments;

e) all sectors need to contribute, but differences exist between sectors on the amount of reductions that can be expected;

f) the low-carbon transition is feasible and affordable.

The problem of external costs of transport including emissions of transport was mentioned in documents of transport policy such as 2009 Future of Transport, Maritime Transport Strategy, 2008 Greening Transport, 2007 Logistics: Keeping Freight moving, Keep Europe moving. The latest strategies of transport policy in this field are 2011 White Paper and 2016 strategy for low-emission mobility.

2011 White Paper.Roadmap to a Single European Transport Area - Towards a competitive and resource efficient transport system (COM/2011/0144 final) consist of 40 initiatives for the next decade to build a competitive transport system that will increase mobility and remove major barriers in key areas. The proposals will reduce Europe's dependence on imported oil and cut carbon emissions in transport by $60 \%$ by 2050 . By 2050, key goals will include (European Strategies, European Commission, 2018): 
a) no conventionally-fuelled cars in cities;

b) $40 \%$ use of sustainable low carbon fuels in aviation; at least $40 \%$ cut in shipping emissions;

c) a $50 \%$ shift of medium distance intercity passenger and freight journeys from road to rail and waterborne transport.

In July 2016 European Commission adopted strategy for low-emission mobility (A European Strategy for Low-Emission MobilityCOM/2016/0501 final). The strategy contains three main elements (Transport emissions, European Commission, 2018):

a) increasing the efficiency of the transport system by making the most of digital technologies, smart pricing and further encouraging the shift to lower emission transport modes;

b) speeding up the deployment of low-emission alternative energy for transport, such as advanced biofuels, electricity, hydrogen and renewable synthetic fuels and removing obstacles to the electrification of transport;

c) moving towards zero-emission vehicles; while further improvements to the internal combustion engine will be needed, Europe needs to accelerate the transition towards low- and zero-emission vehicles.

These transport objectives are monitored annually and are in line with the target for the overall economy. Other transport policies that support the achievement of these goals, such as the various regulations that set $\mathrm{CO}_{2}$ emission targets for new passenger cars and vans, are also monitored in the Transport and Environment Reporting Mechanism (TERM) (European Environment Agency, 2017).

The objectives of European transport and energy policy are convergent in the field of low-carbon economy. They are long term and require the strong international cooperation because both transport and other sectors of economy are global and competitively integrated in the world economy.

\section{EMISSIONS IN INLAND WATERWAY TRANSPORT}

The ecological profile of inland waterway transport was study in two European documents. The first of them was made in 2011 by the Dutch research and consultation organization CE Deft. The actualization of this study was published in 2016 (Hoen, den Boer, Otten, 2016). Ecological impact to the environment was analyzealso in 2017 European Inland Navigation Market Observation. This report is the result of collaboration between the Central Commission for the Navigation of the Rhine (CCNR) and the European Commission and aims at providing yearly an exhaustive view of the inland navigation market situation as well as an analysis of its evolution and developments (Market Observation Inland Navigation in Europe, 2018).

The methodology of the comparison of modes of transport was made in three specific cases, with due allowance being made for the distances travelled by each mode and the up- and downstream transport involved in getting from A to B (Hoen et al., 2016, p. 15). Specific for inland waterway transport the model estimates energy consumption using waterway parameters (depth, width, flow), vessel parameters (length/width, full and empty vessel draught), and operational parameters (sailing speed, load). Load factor affects draught and thus energy consumption. Sailing speeds were differentiated according to waterway class and load status (loaded vs. empty) (Hoen et al., 2016, p. 48). 
The methodology of the comparison of emissions from transport modes consist of two approaches (Market Observation Inland Navigation in Europe, 2018):

a) The well-to-wheel (or well-to-propeller) approach comprises all emissions caused by a transport mode: emissions during fuel extraction, fuel production, fuel transport, and finally the emissions caused by the combustion of fuel in the engines;

b) The tank-to-wheel (or tank-to-propeller) approach contains only those emissions that occur from the combustion of fuel in the engines (of a vessel, a truck or a train).

c) The study of Deft report on both exhaust emissions (tank-to-wheel emissions) and total use-dependent emissions down the supply chain (well-to-wheel emissions) (Hoen et al., 2016, p. 38).

2017 European Inland Navigation Market Observation based on well-to-wheel emissions. The Authors of the research study assumed, that this approach gives a more comprehensive picture of the ecological profile of a mode of transport. This is especially relevant for electric rail transport. About $80 \%$ of European rail traffic uses electric traction today. Therefore, the emissions of rail traffic, based on a tank-to-wheel approach, would be almost zero. But for the generation of electricity, significant emissions can be produced. If electricity is produced by a coal fired power plant for example, the well-to-wheel emissions would be quite high. This is taken into account only by the well-to-wheel approach (Market Observation Inland Navigation in Europe, 2018).

The conclusions of both of the reports indicate that IWT vessels emit relatively few greenhouse gases, but can have rather high values for pollutant emissions, when compared to railways and trucks. For $\mathrm{CO}_{2}$ emissions, all IWT vessel types have lower emissions than the most common truck type (semitrailer), but higher emissions than the most common railway type (electric railway). For pollutant emissions PM and NOx, IWT vessels have higher emissions than electric railways, the most common railway type. If we compare pollutant emissions between IWT and road traffic, we see that one of the most common vessel types (the Large Rhine vessel) as well as the larger vessel types have lower emissions than truck semitrailers. The second very common vessel type, Rhine-Herne-Canal, has higher emissions than the truck semitrailers. It is worth thinking about emission reduction measures specifically for the IWT sector (Market Observation Inland Navigation in Europe, 2018).

Most measures for the reduction of emissions in IWT at the same time also reduce fuel consumption, and therefore have both ecological and economic benefits. Emission factors for $\mathrm{CO}_{2}$ and $\mathrm{SO}_{2}$ depend directly on engine diesel consumption. Emissions of the greenhouse gases $\mathrm{N}_{2} \mathrm{O}$ and $\mathrm{CH}_{4}$ are likewise linearly related to diesel consumption. The NOx and PM emission factors for inland shipping depend on vessel construction year and the emission standards in force in that year (Hoen et al., 2016, p. 51).

Emission reduction measures in inland shipping can be categorized into three main groups (Market Observation Inland Navigation in Europe, 2018):

a) Technical measures: Measures related to the propulsion system, vessel design and vessel equipment, exhaust after treatment, engine internal measures, use of alternative fuel/ energy (LNG, Electricity, Hydrogen, Biofuel);

b) Operational measures: Measures related to speed reduction, smart steaming, journey planning, on board information systems, optimal maintenance; 
c) Traffic \& Transport management: measures related to the organization of the logistical chain, to the interface between inland waterway vessels and other transport modes, to the interface of inland waterway vessels and infrastructure (locks, terminals in inland and seaports, etc.).

For inland-waterway vessels there are a range of alternative fuels and technologies available for application in the current fleet (Hoen et al., 2016, p. 61; Market Observation Inland Navigation in Europe, 2018):

a) LNG (Liquefied Natural Gas) to reduce pollutant emissions ( $80 \%$ for $\mathrm{NO}_{\mathrm{x}}, 75 \%$ for $\mathrm{PM}$ );

b) GTL (Gas-To-Liquid) is an option for reducing the air-pollutant emissions of (older) engines without further engine adaptation;

c) SCR (selective catalytic reduction) to reduce NOx emissions (85-90\% for $\mathrm{NO}_{\mathrm{x}}$ );

d) PMF (particulate matter filters) to reduce pollutant emissions (90-95\% for PM);

e) DPF (diesel particle filters) to reduce particulate emissions;

f) electric propulsion;

g) diesel electric propulsion;

h) father-and-son engine;

i) flexible tunnel;

j) optimized hull form;

k) weight reduction by composite materials.

However, there are side effects of implementing individual solutions especially on the small ships due to the disadvantages of the scale or the insufficient capacity. For example, the SCR and DPF usually require a volume of two or three times the capacity of displacement of the engine. Since engine rooms and engines are in different configurations, the application of SCR and DPF for existing engines often require a case-by-case/tailor made approach (Contribution..., 2013, p. 47).

LNG has high investment costs so it is profitable on the new large ships. Furthermore, the combustion process of LNG is not perfect because the methane slip occurs. Methane slip is very harmful for global warming - its global warming potential is about 28 to 34 times higher than that of $\mathrm{CO}_{2}$. Further technological evolution is needed in order to reduce methane slip (Market Observation Inland Navigation in Europe, 2018).

Exhaust after treatment systems - selective catalytic reduction (SCR) and particulate matter filters (PMF) - are very efficient at reducing pollutant emissions, but for a single engine of some $1,000 \mathrm{~kW}$, which is a common engine size for a self-propelled vessel in Europe, the price for exhaust after treatment systems is almost as high as the price for a new engine. PMF can lead to slightly higher fuel consumption levels by 2-3\% (Market Observation Inland Navigation in Europe, 2018).

The new emission limits (Stage V) that will apply for new engines from 2019 onwards can only be met with single LNG fuel propulsion or with the installation of both exhaust after treatment systems (Market Observation Inland Navigation in Europe, 2018).

New strategy for low-emission mobility in inland waterway transport is electric power. Five autonomous electric barges will begin operating between the De Kempen intermodal terminal in the south of the Netherlands and Antwerp beginning in 2018. They have been designed to fit beneath the many bridges found in the Netherlands and Belgium. The technology for the autonomous ships was made possible through an investment of 7 EUR million by the European Union 
as part of a program to improve port efficiency. The port of Antwerp also invested 200,000 EUR in the project. Apart from the ability to operate autonomously, the batteries of the new vessels are mounted in a container of their own, which means they can be used by existing vessels. This allows to retrofit barges already in operation. The containers are charged onshore by carbon free energy provider Eneco, which sources solar power, windmills and renewables (Clean Technica 2018). Electric propulsion decreases energy consumption of $10 \%$. It estimated cost is $300000 \mathrm{EUR}$ and have 15 years payback time (Market Observation Inland Navigation in Europe, 2018).

Operational measures and Traffic \& Transport management have a very positive cost-benefit ratio and can all be applied in new and retrofit vessels (Market Observation Inland Navigation in Europe, 2018). The examples of operational measures and Traffic \& Transport managementin IWT are(RIS, 2018; Market Observation Inland Navigation in Europe, 2018):

- RIS - River Information Services,

- DINA - Digital Inland Waterways Activity,

- NTS - Notices to Skippers,

- IENC - Inland Electronic Navigational Charts,

- AIS - Automatic Identification System,

- improving interface in seaports,

- reduction off empty trips,

- optimal maintenance,

- on board information system/journey planning,

- speed reduction/smart streaming.

The most important example of operational measures in IWT is River Information System (RIS). RIS are information services designed to enhance safety and efficiency of inland waterway transport by optimizing traffic and transport processes (RIS, 2018). In 2015 the European Commission launched the Digital Inland Waterways Activity (DINA) initiative. Goal of the DINA initiative is to digitize information flows in IWT with the aim to allow for seamless integration of IWT in multimodal logistic chains (RIS, 2018).

European Commission, Mobility and Transport DG, carried out two studies that contribute to sustainable IWT by strengthening the electronic and digital tools in IWT:

a) 2016 eIWT Electronic tool for Inland Waterways Transport;

b) 2017 Digital Inland Waterway Area: Towards a Digital Inland Waterway Area and Digital Multimodal Nodes.

Digitalization is necessary to improve the competitiveness of inland waterway transport. Data sharing amongst all actors related to inland waterway transport can improving the competitiveness of this transport mode. Developments in other modes of transport and new trends in digital technologies impact digitalization in inland waterway transport. Digitalization is needed to avoid IWT lagging behind other modalities (Contribution..., 2013). Digitalization is also the tool to provide multimodal integration. This could incentivize a modal shift towards inland waterway transport. 


\section{CONCLUSION}

One of the main challenges on the way of economic development is low carbon economy. An essential component of the shift to the low-carbon, circular economy is low-emission mobility. Low emission mobility is one of the goals set by the transport policy building competitive and resource efficient transport system.The objectives of European transport and energy policy are convergent in the field of low-carbon economy. They are long term and require the strong international cooperation because both transport and other sectors of economy are global and competitively integrated in the world economy.

Energy and climate policies accelerated the potential of transport to shift towards low emission mobility. In addition, promoting multimodality will strength the shift towards lower emission transport modes such as inland waterway transport and rail. The modal shift may result in an increase of emissions from IWT in the next years. To be competitive IWT need to develop measures and strategies towards reduction of the negative impact on the environment and increasing energy efficiency.

Characteristics of the IWT are the longevity of engines, less stringent emission limits for inland shipping compare to the other land-based modes of transport and the relatively small and specific market for inland vessels causes disadvantages of scale. These qualities determine most measures for reduction of emission in IWT.

The IWT vessels emit relatively few greenhouse gases, but can have rather high values for pollutant emissions, when compared to railways and trucks. Most measures for the reduction of emissions in IWT at the same time also reduce fuel consumption, and therefore have both ecological and economic benefits. However, there are side effects of implementing individual solutions especially on the small ships due to the disadvantages of the scale or the insufficient capacity.

New strategy for low-emission mobility in inland waterway transport is electric power. Five electric power barges operate in the Netherlands and Belgium. Converting inland ships to electric power is an interface between technology and sustainability.

Developments in other modes of transport and new trends in digital technologies impact digitalization in inland waterway transport. Digitalization is also the tool to provide multimodal integration. This could incentivize a modal shift towards inland waterway transport.

\section{REFERENCES}

2030 climate and energy framework (2018). European Commission. Retrieved from: https://ec.europa.eu/clima/policies/ strategies/2020_en (7.07.2018).

Clean Air campaign (2018). Retrieved from:http://www.cleanair-europe.org/en/projects/bund/clean-inland-shipping/ (7.07.2018).

Communication from the Commission to the European Parliament, the Council, the European Economic and Social Committee and the Committee of the Regions. A European Strategy for Low-Emission Mobility (2016) COM/2016/0501 final.

Communication from the Commission to the European Parliament, the Council, the European Economic and Social Committee and the Committee of the Regions. Energy Roadmap 2050 (2011) COM/2011/885. Retrieved from https://eur-lex.europa.eu/LexUriServ/LexUriServ.do?uri=COM:2011:0885:FIN:EN:PDF (10.7.2018). 
Contribution to impact assessment of measures for reducing emissions of inland navigation (2013). Panteia. Retrieved from: https://ec.europa.eu/transport/sites/transport/files/modes/inland/studies/doc/2013-06-03-contributionto-impact-assessment-of-measures-for-reducing-emissions-of-inland-navigation.pdf (7.07.2018).

Dutch Company Introduces Autonomous Electric Barge in Europe, “Clean Technica” (2018). Retrived from: https:// cleantechnica.com/2018/01/13/dutch-company-introduces-autonomous-electric-barge-europe/ (8.07.2018).

European Commission, climate negotiation. Retrieved from: https://ec.europa.eu/clima/policies/international/negotiations/paris_en (8.07.2018).

European Environment Agency (2017). Retrieved from: https://www.eea.europa.eu/data-and-maps/indicators/transport-emissions-of-greenhouse-gases/transport-emissions-of-greenhouse-gases-10 (7.07.2018).

European Strategies, European Commission (2018). Retrieved from https://ec.europa.eu/transport/themes/strategies/2011_white_paper_en (7.07.2018).

Eurostat (2018). Retrieved from: http://ec.europa.eu/eurostat/statistics-explained/index.php/Greenhouse_gas_emission_statistics.

Hoen, M., den Boer, E., Otten, M. (2016). STREAM Freight transport 2016. Retrieved from: https://www.cedelft.eu/ publicatie/stream_freight_transport_2016/1855 (25.06.2018).

Keuken, M.P., Moerman, M., Jonkers, J., Hulskotte, J., Denier van der Gon, H.A.C., Hoek, G., Sokhi, R.S. (2014). Impact of inland shipping emissions on elemental carbon concentrations near waterways in The Netherlands. Retrieved from: https:/www.researchgate.net/publication/263088683_Impact_of_inland_shipping_emissions_on_elemental_carbon_concentrations_near_waterways_in_The_Netherlands (7.07.2018).

Market Observation Inland Navigation in Europe Annual Report (2017). Retrieved from: https://www.inland-navigation-market.org/en/rapports/2017/q2/9-emissions-in-inland-navigation/ (7.07.2018).

RIS (2018). Retrieved from: http://www.ris.eu/general/what_is_ris_/description (7.07.2018).

Siegemund, S., Trommler, M., Kolb, O., Zinnecker, V. (2017). "E-fuels” Study, The potential of electricity-based fuels for low-emission transport in the EU. An expertise by LBST and DENA. Retrieved from: https://shop.dena.de/ fileadmin/denashop/media/Downloads_Dateien/verkehr/9219_E-FUELS-STUDY_The_potential_of_electricity_based_fuels_for_low_emission_transport_in_the_EU.pdf (7.07.2018).

Transport emissions, European Commission (2018). Retrieved from: https://ec.europa.eu/clima/policies/transport_en (25.06.2018).

White Paper. Roadmap to a Single European Transport Area - Towards a competitive and resource efficient transport system COM(2011) 144 final. Retrieved from: http://eur-lex.europa.eu/LexUriServ/LexUriServ.do?uri=COM:2 011:0144:FIN:en:PDF (25.06.2018).

\section{Emisje w transporcie wodnym sródlądowym w kontekście polityki energetycznej, klimatycznej i transportowej Unii Europejskiej}

Niskoemisyjna mobilność jest jednym z głównych celów europejskiej polityki transportowej. Polityki energetyczna i klimatyczna wzmacniają potencjał transportu do zmiany w kierunku mobilności niskoemisyjnej. Dodatkowo promocja multimodalności przyspiesza przesunięcie w kierunku niskoemisyjnych gałęzi transportu, takich jak transport wodny śródlądowy i kolejowy. Pomimo że transport wodny śródlądowy nie jest głównym źródłem zanieczyszczeń w Unii Europejskiej, przesunięcie gałęziowe może skutkować zwiększeniem emisji w tej gałęzi transportu w kolejnych latach. Celem artykułu jest analiza emisji w żegludze śródlądowej w kontekście polityki energetycznej, klimatycznej i transportowej, w szczególności środków służących redukcji emisji w transporcie wodnym śródlądowym.

W celu prześledzenia tych zagadnień przeanalizowane zostały ostatnie dokumenty polityki energetycznej, klimatycznej i transportowej. Porównane zostały rezultaty dwóch studiów badawczych nad emisjami ze statków rzecznych w celu opisu efektywności energetycznej żeglugi i jej zdolności do włączenia się w cele wyznaczone przez politykę niskoemisyjnej mobilności. 
Transport wodny śródlądowy charakteryzuje się długą żywotnością silników, mniej rygorystycznymi limitami emisji w porównaniu do innych gałęzi transportu lądowego, jak również relatywnie małym i specyficznym rynkiem statków rzecznych, który tworzy niekorzyści skali. Te cechy determinują większość środków redukcji emisji w żegludze śródlądowej.

Statki rzeczne emitują relatywnie mniej gazów cieplarnianych, lecz więcej zanieczyszczeń w porównaniu do transportu samochodowego i kolejowego. Większość środków redukcji emisji w żegludze śródlądowej zmniejsza także zużycie paliwa. Przynoszą więc one zarówno korzyści ekologiczne, jak i ekonomiczne.

Nową strategią niskoemisyjnej mobilności w transporcie wodnym śródlądowym jest zasilanie elektryczne. Zmiana zasilania statków w kierunku napędu elektrycznego jest połączeniem technologii i zrównoważonego rozwoju.

Digitalizacja jest konieczna dla poprawy konkurencyjności transportu wodnego śródlądowego. Jest ona również narzędziem integracji międzygałęziowej. Może być impulsem do przesunięcia gałęziowego w kierunku żeglugi śródlądowej.

transport wodny śródlądowy, polityka transportowa, polityka energetyczna i klimatyczna 